\title{
Hypertension and transcatheter aortic valve replacement: parallel or series?
}

This article was published in the following Dove Press journal: Integrated Blood Pressure Control

\author{
Nidhish Tiwari ${ }^{1,2}$ \\ Nidhi Madan ${ }^{3}$ \\ 'Department of Internal Medicine, \\ Jacobi Medical Center, Bronx, NY, \\ USA; ${ }^{2}$ Department of Internal \\ Medicine, Albert Einstein College \\ of Medicine, Bronx, NY, USA; \\ ${ }^{3}$ Department of Cardiology, Rush \\ University Medical Center, Chicago, \\ IL, USA
}

Correspondence: Nidhish Tiwari Department of Internal Medicine, Jacobi Medical Center, 5-East 2, Building One, 1400 Pelham Parkway South, Bronx, NY 1046I, USA

$\mathrm{Tel}+\mid$ 7| $8-9|8-590|$

Fax +l 8885882920

Email nidhish.tiwari@nychhc.org

\begin{abstract}
Aortic stenosis (AS) is the most common valvular heart disease in the elderly and it causes significant morbidity and mortality. Hypertension is also highly prevalent in elderly patients with AS, and AS patients with hypertension have worse outcomes. Accurate assessment of AS severity and understanding its relationship with arterial compliance has become increasingly important as the options for valve management, particularly transcatheter interventions, have grown. The parameters used for quantifying stenosis severity have traditionally mainly focused on the valve itself. However, AS is now recognized as a systemic disease involving aging ventricles and stiff arteries rather than one limited solely to the valve. Over the last decade, valvuloarterial impedance, a measure of global ventricular load, has contributed to our understanding of the pathophysiology and course of AS in heterogeneous patients, even when segregated by symptoms and severity. This review summarizes our growing understanding of the interplay between ventricle, valve, and vessel, with a particular emphasis on downstream vascular changes after transcatheter aortic valve replacement and the role of valvuloarterial impedance in predicting left ventricular changes and prognosis in patients with various transvalvular flow patterns.
\end{abstract}

Keywords: aortic stenosis, transcatheter aortic valve replacement, global ventricular load, ventriculoarterial coupling, arterial compliance, valvuloarterial impedance

\section{Introduction}

The clinical picture of aortic stenosis (AS) is now markedly different to that elegantly described by Braunwald 50 years ago, where male patients with AS had an average life expectancy of only 63 years. ${ }^{1}$ AS is no longer regarded as a disease of young patients with an isolated rheumatic deformity and perfect vessel compliance, where the only life-prolonging treatment was open valve surgery with bypass support. Now, patients are often elderly with atherosclerosis, calcific degenerative aortic valve disease, hypertension, stiff vessels, and a non-compliant ventricle (Figure 1). There are also several management options, with a variety of valves and routes via the transcatheter approach (transcatheter aortic valve replacement; TAVR).

AS is common, affecting over $12 \%$ of patients over 75 years in North America and Europe. ${ }^{2}$ Approximately one-third of patients with symptomatic $\mathrm{AS}^{3}$ and two-thirds of asymptomatic AS patients have co-existing hypertension ${ }^{4}$ and, conversely, hypertension contributes a $20 \%$ increase in risk of developing AS. ${ }^{5}$ In the simvastatin and ezetimibe in AS (SEAS) trial examining patients with asymptomatic mild-to-moderate AS, hypertension was associated with a $56 \%$ higher rate of ischemic cardiovascular events and a two-fold increase in mortality, independent of AS severity or valve replacement. ${ }^{6}$ It 


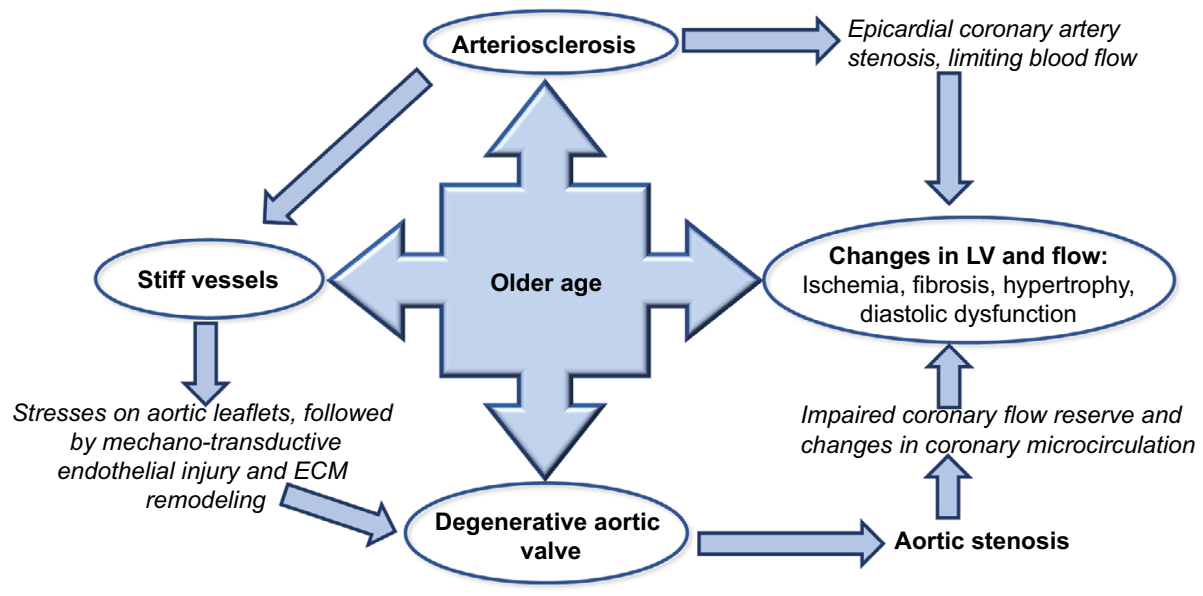

Figure I Direct and indirect effects of age on ventricular valvular vessel interactions. Abbreviations: ECM, extracellular matrix; LV, left ventricle.

is now clear that the aortic valve gradient alone does not represent the disease in totality in elderly patients with multiple comorbidities. Traditional methods of quantifying valvular stenosis that focus only on the valve do not fully quantify or capture disease severity, correlate with symptoms, or fully prognosticate. Over the last decade, new perspectives on the AS pathophysiology have resulted in a new, four flow gradient pattern classification system (Table 1) that dismisses the previous misconception that patients with AS and normal left ventricular ejection fraction (LVEF) have normal flow.

\section{Pathophysiological mechanism}

AS results in blood flow through a narrow valve, which subsequently leads to compensatory morphological changes in the left ventricle (LV), such as hypertrophy and fibrosis. There occurs concentric hypertrophy of the LV in response to the pressure overload caused by AS. This concentric hypertrophy is both adaptive and maladaptive. The hypertrophied myocardium helps the ventricle to propel blood against the stenotic aortic valve, however, it has poor coronary flow reserve, even in presence of normal epicardial arteries. This can lead to both systolic and diastolic dysfunction of the LV. Additionally, the increase in the myocardial mass results in increased myocardial demand and can manifest as myocardial ischemia, angina, and dyspnea in these patients.

\section{Hypertension: introducing valvuloarterial impedance ( $Z \mathrm{Va})$, systemic arterial compliance (SAC), and resistance in series}

Vascular stiffness is a well-known consequence of aging. However, it also occurs with atherosclerosis, hypertension, dyslipidemia, and diabetes. ${ }^{7,8}$ Increase in arterial stiffness results in higher LV afterload and myocardial oxygen demand, ${ }^{4}$ and is related to increased risk of cardiovascular events., ${ }^{9} 10$ Studies also suggest that inflammation plays a role in arterial stiffness and may have a role in targeting therapies. ${ }^{11}$

In an abstracted model, assuming non-pulsatile flow, ventricular and arterial loads can be modeled as resistance-inseries to calculate the total afterload that the aging ventricle must overcome to propel blood through the macro and micro vasculature. In AS patients, this resistance-in-series model has been explored and represented in clinically measurable values like SAC and ZVa. ${ }^{12}$

Ventricular load is often represented as the mean gradient generated across the stenosed AV ignoring the intraventricular pressure gradient. In contrast, arterial load has two major components: steady load (resistance), generated largely by the microcirculation, and pulsatile load, which is dependent on conduit vessels. The resistive component of arterial load, or systemic vascular resistance (SVR), can be calculated as the ratio of mean arterial pressure/cardiac output (CO) and remains constant. SAC is a surrogate of pulsatile load, that is the ability of the arterial wall to accommodate an increased volume with increasing transmural pressure. SAC is a complex variable that is dependent on time (vessel) and frequency (ventricle), and it can accurately be assessed with detailed modeling of aortic pressure-flow relationships. Clinically, SAC is calculated as the LV stroke volume indexed for body surface area $(\mathrm{SVi})$ divided by the aortic pulse pressure $(\mathrm{PP})^{12}$ :

$$
S A C=\frac{S V i}{P P}
$$

Increased aortic wall stiffness or decreased total arterial compliance augments the velocity of the pressure wave and, as a consequence, the reflected wave arrives at the aortic root earlier than intended when the ventricle is still in late systole. This increases the systolic arterial pressure (SAP) and LV afterload while simultaneously removing the augmentation 
Table I Prevalence and prognosis and percentage of patients with severe AS

\begin{tabular}{|c|c|c|}
\hline & High gradient (mean $>40 \mathrm{mmHg}$ ) & Low gradient (mean $<40 \mathrm{mmHg}$ ) \\
\hline $\begin{array}{l}\left.\text { Normal flow (SV }>\mathbf{3 5} \mathbf{~ m L} / \mathbf{m}^{2}\right) \\
\text { A) Prevalence } \\
\text { B) Prognosis (2-year survival rates) }\end{array}$ & $\begin{array}{l}30 \%-62.7 \% \\
44 \% \pm 6 \% \\
\text { (highest rates of surgery) }\end{array}$ & $\begin{array}{l}15.3 \%-38 \% \\
83 \% \pm 6 \% \text { (best prognosis) }\end{array}$ \\
\hline $\begin{array}{l}\text { Low flow }\left(\mathbf{S V}<\mathbf{3 5} \mathbf{~ m L} / \mathbf{m}^{2}\right) \\
\text { A) Prevalence } \\
\text { B) Prognosis (2-year survival rates) }\end{array}$ & $\begin{array}{l}8 \%-13.2 \% \\
30 \% \pm 12 \%\end{array}$ & $\begin{array}{l}8.8 \%-24 \% \\
27 \% \pm 13 \% \text { (worst prognosis) } \\
\text { (lowest rates of surgery) }\end{array}$ \\
\hline
\end{tabular}

Abbreviations: AS, aortic stenosis; SV, stroke volume.

meant for the diastolic pressure. As a result, a decrease in SAC causes isolated systolic hypertension and widening of the PP. In severe AS patients, the hallmark feature of a prolonged LV ejection time provides even greater opportunity for the reflected pressure wave to meet the LV in late systole. The result is worsening ventriculoarterial coupling, reduced global cardiovascular efficiency, and increased myocardial oxygen demand. Coronary perfusion may also be affected due the decreased diastolic pressure. Congestive heart failure, ventricular hypertrophy, and vascular remodeling are all associated with increased pulsatile ventricular workload. As we already know from Starling's seminal studies, at a given contractility, simply increasing afterload will decrease stroke volume. In the long run, this inefficient mechanics leads to heart failure.

In elderly patients with degenerative AS, which is frequently accompanied by increased arterial stiffness or decreased compliance, there is additional load on the LV that cannot be fully explained by the mean pressure gradient across the AV (MPG). ZVa represents the sum of valvular and arterial factors that oppose ventricular ejection by absorbing the mechanical energy developed by the $\mathrm{LV} .{ }^{12} \mathrm{ZVa}$ is the ratio of the sum of SAP (either brachial or central aortic) ${ }^{13}$ and mean pressure gradient (MPG) across the $\mathrm{AV},{ }^{12}$ to the stroke volume index (SVi), and it is a surrogate for global left ventricular load:

$$
Z V a=\frac{S A P+M P G}{S V i}
$$

ZVa has been studied as a prognostic factor in both asymptomatic AS patients and those undergoing TAVR, reviewed below.

\section{Changes in blood pressure (BP) and arterial compliance post TAVR: immediate, mid, and long term}

The hemodynamic changes in patients' post TAVR are summarized in Table 2. Hypertension develops in 50\% of patients after TAVR. Interestingly, patients with increased
BP after TAVR have a better prognosis and outcomes. ${ }^{14-16}$ The nature of the complex vascular-valvular interaction has been revealed by changes in compliance properties post AS intervention. To add more complexity, complementarity (both compartments contribute additively to afterload) and competitivity (one compartment cannot be lowered without raising the other one) under constant contractility and preload exist, meaning that the vascular-valvular interaction is more pronounced in severe AS. ${ }^{17}$ In the most precise study using high-fidelity sensors, including frequency domain and wave intensity analyses, as soon as the ventricular obstruction is removed, that is, immediately after TAVR (30 minutes), the LV generated stronger forward compression waves that were reflected as stronger backward compression waves to the LV. Both effects caused increase in systolic and mean arterial pressure and widening of the PP. Post TAVR, the SVR increased, the SAC decreased (inducing stiffer vascular behavior), and the SVi and $\mathrm{CO}$ also decreased. ${ }^{15}$ There was no acute improvement in ZVa. ${ }^{15}$ This paradoxical effect of increase in continuous and pulsatile vascular load after TAVR suggests a stiffer response of the vascular tree and has previously been described. ${ }^{14}$ The authors of this study postulate that this finding could be due to the viscoelastic properties of the large conductance arteries and the changes in the tone of these large arteries and arterioles. ${ }^{15}$

However, these results were not reproducible in other studies in which these variables were measured immediately after TAVR based on transthoracic echocardiography (TTE); only ZVa decreased and there were improvements in SAC, SVi, SVR, and $\mathrm{CO}^{18}$ and even normalization of arterioventricular coupling. ${ }^{19}$ In another study using right heart catheterization, systolic blood pressure (SBP) and PP increased with a reduction in SVR 24 hours after TAVR. ${ }^{20}$ The elastic properties of the ascending aorta, namely aortic distensibility and the aortic stiffness index, did not change significantly in the early post-procedural period, that is, seven days after TAVR ${ }^{21}$ Also, a retrospective non-invasive TTE 
Table 2 Hemodynamic changes post TAVR

\begin{tabular}{|c|c|c|c|c|c|c|c|c|c|}
\hline First author, year & $\begin{array}{l}\text { Time post } \\
\text { TAVR }\end{array}$ & $\begin{array}{l}\text { Techniques used } \\
\text { for measuring } \\
\text { hemodynamic } \\
\text { parameters }\end{array}$ & SBP & MAP & $\begin{array}{l}\text { Pulse } \\
\text { pressure }\end{array}$ & $\begin{array}{l}\text { Cardiac } \\
\text { output/ } \\
\text { cardiac } \\
\text { index }\end{array}$ & LVEF & $\begin{array}{l}\text { Stroke } \\
\text { volumel } \\
\text { SVi } \\
\text { (indexed) }\end{array}$ & ZVa \\
\hline Giannini, ${ }^{18} 2012$ & $\begin{array}{l}\text { Within } 10-15 \\
\text { minutes }\end{array}$ & $\begin{array}{l}\text { Invasive (cardiac } \\
\text { catheterization) and } \\
\text { Echocardiography }\end{array}$ & $\uparrow$ & $\downarrow$ & $\uparrow$ & $\uparrow($ Mild) & $\uparrow \uparrow$ & $\uparrow$ (Mild) & $\downarrow$ \\
\hline Di Bello, ${ }^{19} 2012$ & $\begin{array}{l}\text { Within } 10-15 \\
\text { minutes }\end{array}$ & $\begin{array}{l}\text { Invasive } \\
\text { hemodynamics and } \\
\text { Echocardiography }\end{array}$ & $\uparrow$ & $\downarrow$ & $\begin{array}{l}\uparrow \\
\end{array}$ & $\uparrow$ & $\uparrow \uparrow$ & $\uparrow$ & \\
\hline Yotti, $^{15} 2015$ & 30 minutes & $\begin{array}{l}\text { Invasive (high fidelity } \\
\text { sensors and wave } \\
\text { intensity analyses) }\end{array}$ & $\uparrow$ & $\uparrow$ & $\begin{array}{l}\uparrow \\
\end{array}$ & $\downarrow$ & & $\downarrow$ & $\begin{array}{l}\text { No acute } \\
\text { change }\end{array}$ \\
\hline Perlman, ${ }^{16} 2013$ & 5 days & TTE & $\uparrow$ & & $\uparrow$ & $\uparrow$ & & $\uparrow$ & \\
\hline Vavuranakis, ${ }^{21} 2012$ & 7 days & TTE & $\downarrow$ & $\downarrow$ & \begin{tabular}{|l|}
$\uparrow$ \\
$\imath$
\end{tabular} & & & & \\
\hline Lindman, ${ }^{43} 2017$ & $\begin{array}{l}30 \text { days and } 6 \\
\text { months }\end{array}$ & TTE & $\uparrow$ & & $\uparrow$ & & & $\uparrow$ & $\downarrow$ \\
\hline Katsanos, ${ }^{22} 2013$ & $\begin{array}{l}30 \text { days and } \\
\text { I year }\end{array}$ & TTE & & & & & & $\begin{array}{l}\text { No } \\
\text { significant } \\
\text { change }\end{array}$ & $\downarrow$ \\
\hline
\end{tabular}

Abbreviations: LVEF, left ventricular ejection fraction; MAP, mean arterial pressure; SBP, systolic blood pressure; SVi, stroke volume indexed to body surface area; TAVR, transcatheter aortic valve replacement; TTE, transthoracic echocardiography; ZVa, valvuloarterial impedance.

study showed that only ZVa was decreased but not SAC or SVR at 30 days and 1 year after TAVR. ${ }^{22}$ This was also shown in prospective study, where ZVa decreased at 1 month and 1 year after TAVR. ${ }^{23}$

Although echo-Doppler-based non-invasive and catheterbased invasive measurements of pulse wave velocity (PWV) showed a good correlation as a measure of aortic stiffness, ${ }^{24}$ some aspects of the protocol and the small sample size of typical TAVR patients made generalization difficult.

\section{Changes in BP and arterial compliance post surgical aortic valve replacement (SAVR)}

The aforementioned results contrast with those from patients undergoing SAVR with cardiopulmonary bypass (Table 3), in which SAC, PP, and SV remain unchanged but ZVa decreased 15 minutes ${ }^{25}$ after and even at 12 months ${ }^{26}$ after cardiopulmonary bypass. Interestingly, TAVR patients exhibited a greater percent reduction in ZVa than SAVR patients as measured by TTE at 2 months. ${ }^{27}$ Similarly, using cardiovascular magnetic resonance measurements of aortic distensibility and PWV, treatment of symptomatic severe AS by SAVR but not TAVR was associated with an increase in aortic stiffness at 6 months. ${ }^{28}$ In another study, SAC measured by TTE did not decrease 12 months after SAVR, but there was a significant decrease in $\mathrm{ZVa}^{26}$

\section{ZVa and prognosis: a review of the data}

Pioneering work by Briand et $\mathrm{al}^{12}$ showed that high $\mathrm{ZVa}$ was an independent predictor of both systolic and diastolic LV dysfunction. Since then, the impact of ZVa and SAC on LV remodeling, prognosis in asymptomatic AS patients, relationship between ZVa and AS symptoms, and mortality outcomes have been investigated. These are detailed below and summarized in Table 4 highlighting time of observation, method of observation, and patient population.

\section{Remodeling}

The correlation between pre-AVR ZVa and decrease in LV mass index (LVMi) was shown in a retrospective study with a median follow-up of almost 3.5 years after SAVR, and ZVa performed better than classic indices of AS severity, such as aortic valve area (AVA) and MPG. ${ }^{29}$ This also held true for postTAVR cohort, where ZVa measured 12 months after TAVR (but not SBP, MPG, or SAC) was a significant predictor of LVMi regression as measured by M-mode echocardiography. ${ }^{26}$ Higher ZVa but not PWV or other indices of AS severity were associated with lower global longitudinal strain (GLS) in severe AS patients with preserved LVEF, ${ }^{13}$ and a reduction in $\mathrm{ZVa} 1$ month after TAVR correlated significantly with improvement in GLS at 1 month and 1 year. ${ }^{23}$ In patients with asymptomatic severe AS and preserved LVEF, a high ZVa was also associated with worse circumferential strain ${ }^{30}$ and decreased stress-corrected 
Table 3 Hemodynamic changes post SAVR

\begin{tabular}{|c|c|c|c|c|c|c|c|c|c|}
\hline $\begin{array}{l}\text { First } \\
\text { author, } \\
\text { year }\end{array}$ & $\begin{array}{l}\text { Time post } \\
\text { SAVR }\end{array}$ & $\begin{array}{l}\text { Technique used } \\
\text { for measuring } \\
\text { hemodynamic } \\
\text { parameters }\end{array}$ & SBP & MAP & $\begin{array}{l}\text { Pulse } \\
\text { pressure }\end{array}$ & $\begin{array}{l}\text { Cardiac } \\
\text { output/ } \\
\text { cardiac } \\
\text { index }\end{array}$ & LVEF & $\begin{array}{l}\text { Stroke } \\
\text { volume/SVi } \\
\text { (indexed) }\end{array}$ & ZVa \\
\hline Pagel, ${ }^{25} 2014$ & $\begin{array}{l}\text { I } 5 \text { minutes after } \\
\text { cardiopulmonary } \\
\text { bypass }\end{array}$ & TEE & $\begin{array}{l}\text { No } \\
\text { change }\end{array}$ & $\begin{array}{l}\text { No } \\
\text { change }\end{array}$ & No change & No change & No change & No change & $\downarrow$ \\
\hline Ito, ${ }^{26} 2017$ & $\begin{array}{l}\text { Before discharge } \\
\text { and } 6 \text { months } \\
\text { post procedure }\end{array}$ & TTE & & $\begin{array}{l}\text { No } \\
\text { change }\end{array}$ & & & & & $\downarrow$ \\
\hline
\end{tabular}

Abbreviations: LVEF, left ventricular ejection fraction; MAP, mean arterial pressure; SAVR, surgical aortic valve replacement; SBP, systolic blood pressure; SVi, stroke volume indexed to body surface area; TEE, trans-esophageal echocardiography; TTE, transthoracic echocardiography; ZVa, valvuloarterial impedance.

midwall shortening. ${ }^{31}$ In a smaller cohort of 82 patients with newly diagnosed severe AS and preserved LVEF, high LV apical rotation (torsion) was associated with high $\mathrm{ZVa} .^{32}$

\section{Prognosis in asymptomatic patients}

In a retrospective sub-study of mild-to-moderate asymptomatic AS patients in the SEAS trial with a mean follow-up of 43 months, high ZVa was associated with a $49 \%$ increased rate of major cardiovascular events and a 55\% increased rate of aortic valve events, but it had no effect on all-cause mortality. ${ }^{33}$ In an observational study of severe and moderate AS patients, a higher number of symptomatic patients had high vascular loads compared with asymptomatic patients in each severity group. ${ }^{34}$ In a small prospective study of asymptomatic severe AS patients with preserved LVEF, high ZVa at baseline was associated with symptom onset, AVR, or death at almost 1 year of follow-up. ${ }^{35}$ This was reproduced in a larger prospective study of 163 patients with asymptomatic moderate-to-severe AS and preserved LVEF, with higher ZVa predicting an increased risk of developing symptoms, cardiac death, and need for AVR at 20 months. ${ }^{36}$ High ZVa was associated with increased all-cause mortality in a retrospective study of patients with asymptomatic, moderate-to-severe AS with preserved LVEF even after correcting for AVR with a median follow-up of 2 years. ${ }^{37}$ In a large retrospective study of severe AS patients, high ZVa measured invasively by cardiac catheterization was an independent predictor of mortality at 4.5 years, even in asymptomatic patients. ${ }^{38}$ In the longest follow-up study of 8.9 years of asymptomatic patients with severe AS but preserved LVEF, higher baseline ZVa was independently associated with a continuously increasing risk of death (for every 0.1 absolute value impairment), even in the patients who had AVR. ${ }^{39}$

\section{Symptoms}

A retrospective study by Kruszelnicka et al showed that lower SAC was associated with more advanced New York Heart
Association class in AS patients, irrespective of LVEF or AS severity in moderate-to-severe AS patients. ${ }^{40}$ This finding corroborates with prior evidence relating arterial stiffness to LV dysfunction ${ }^{41}$ and suggests that interventions targeting elastic properties of the larger arteries may delay symptom onset in AS patients. On the other hand, another retrospective study by Harada et al showed that higher ZVa was associated with syncope in moderate and severe AS patients with LVEF $>40 \%$, irrespective of AVA and MPG. ${ }^{42}$ Syncope in AS patients portends a grave prognosis. The study by Harada et $\mathrm{al}^{42}$ evaluated $\mathrm{ZVa}$, which is a marker of the global LV afterload, and is not one of the conventional factors in AS is associated with increased risk of syncope.

\section{Mortality}

Data from the PARTNER-I cohort showed that increased total and pulsatile arterial load indices (SAC and PP) but not resistive load (SVR) were associated with increased all-cause mortality. A lower 30-day SBP (<129 mmHg) was associated with a higher rate of myocardial infarction, repeat hospitalizations, more severe angina, lower LVEF, inability to complete a six-minute walk test, worse quality of life, and higher all-cause mortality between 30 days and 1 year. Patients with low 30-day SBP and high pulsatile load had a three-fold higher mortality than those with high 30-day SBP and low pulsatile load. ${ }^{43}$

In a prospective study of 128 patients undergoing TAVR, $\mathrm{ZVa}$ at baseline was a better predictor of mortality at 1 year, while SVi and GLS did not differentiate outcomes. ${ }^{23}$ This finding was consistent with other studies showing that higher baseline ZVa was associated with higher mortality at both 6 months and 2 years after TAVR. ${ }^{18,22}$ However, this result was again different in SAVR patients; a retrospective analysis of 170 elderly patients with AS and preserved ejection fraction followed for 5 years revealed that ZVa was not associated with all-cause mortality. However, this study had several 
Table 4 Studies of valvuloarterial impedance $\left(Z_{\mathrm{va}}\right)$ in aortic stenosis patients

\begin{tabular}{|c|c|c|c|c|c|c|}
\hline $\begin{array}{l}\text { First author, } \\
\text { year }\end{array}$ & \begin{tabular}{|l} 
Total \\
number of \\
patients \\
studied, $\mathbf{N}$
\end{tabular} & $\begin{array}{l}\text { Severity of } \\
\text { AS in study } \\
\text { population at } \\
\text { baseline }\end{array}$ & $\begin{array}{l}\text { Baseline } \\
\text { LVEF, \% } \\
\text { (mean } \pm \\
\text { SD) }\end{array}$ & $\begin{array}{l}\text { Mean } \\
\text { follow-up }\end{array}$ & Technique & $\begin{array}{l}\text { Main findings } \\
\text { (ZVa values are } \\
\text { described in } \\
\mathrm{mmHg} / \mathrm{ml}^{\prime} \mathrm{m}^{2} \text { ) }\end{array}$ \\
\hline \multicolumn{7}{|c|}{ ZVa and cardiac remodeling in AS } \\
\hline Jang, ${ }^{29} 2016$ & 453 & Severe & $58.7 \pm 12.1$ & 3.5 years & TTE & $\begin{array}{l}\text { Pre-SAVR ZVa (mean } \\
\text { of 5.9) correlated with } \\
\text { decrease in LV mass } \\
\text { index }\end{array}$ \\
\hline Ito, ${ }^{26} 2017$ & 23 & Severe & $61.5 \pm 11.5$ & $\begin{array}{l}26.5 \pm 10.7 \\
\text { months }\end{array}$ & TTE & $\begin{array}{l}\text { Post TAVR ZVa (from } \\
5.05 \text { pre-procedure to } \\
3.12 \text { post-procedure) } \\
\text { predicted LV mass } \\
\text { index regression }\end{array}$ \\
\hline $\begin{array}{l}\text { Maréchaux, }{ }^{13} \\
2010\end{array}$ & 82 & $\begin{array}{l}\text { AV stenosis, } \\
\text { defined by peak } \\
\text { aortic velocity } \\
>2.5 \mathrm{~m} / \mathrm{s}\end{array}$ & $64 \pm 7$ & - & $\begin{array}{l}\text { TTE with 2-D } \\
\text { speckle tracking }\end{array}$ & $\begin{array}{l}\text { Higher } Z V \text { a associated } \\
\text { with impairment in } \\
\text { global longitudinal } \\
\text { strain }\end{array}$ \\
\hline $\begin{array}{l}\text { Lancellotti, }^{30} \\
2010\end{array}$ & 173 & Severe & $66.5 \pm 7.3$ & - & $\begin{array}{l}\text { TTE with 2-D } \\
\text { speckle tracking }\end{array}$ & $\begin{array}{l}\text { High } \mathrm{ZVa}(\geq 5) \\
\text { associated with worse } \\
\text { circumferential strain }\end{array}$ \\
\hline $\begin{array}{l}\text { Holmes, } \\
2015\end{array}$ & 82 & Severe & $66 \pm 9$ & $\begin{array}{l}33 \pm 17 \\
\text { months }\end{array}$ & $\begin{array}{l}\text { TTE with 2-D } \\
\text { speckle tracking }\end{array}$ & $\begin{array}{l}\text { High LV apical rotation } \\
\text { (torsion) associated } \\
\text { with high ZVa (5.03) } \\
\text { and poor survival. }\end{array}$ \\
\hline $\begin{array}{l}\text { Cramariuc, }{ }^{31} \\
2009\end{array}$ & 1,591 & $\begin{array}{l}\text { AS defined as } \\
\text { AV thickening } \\
\text { accompanied by a } \\
\text { peak transaortic } \\
\text { velocity } \geq 2.5 \\
\text { and } \leq 4.0 \mathrm{~m} / \mathrm{s}\end{array}$ & $66 \pm 7$ & - & TTE & $\begin{array}{l}\text { High ZVa }(\geq 4.48) \\
\text { was associated with } \\
\text { decreased stress- } \\
\text { corrected midwall } \\
\text { shortening }\end{array}$ \\
\hline \multicolumn{7}{|c|}{ ZVa in Asymptomatic AS patients } \\
\hline $\begin{array}{l}\text { Ramamurthi, }{ }^{34} \\
2013\end{array}$ & 215 & $\begin{array}{l}\text { Moderate and } \\
\text { severe }\end{array}$ & & - & TTE & $\begin{array}{l}\text { Higher number of } \\
\text { symptomatic patients } \\
\text { had increased } Z \mathrm{Va} \\
(>5) \text { compared with } \\
\text { asymptomatic patients }\end{array}$ \\
\hline Zito, 2011 & 52 & Severe & $6 \mathrm{I} \pm 5$ & $\begin{array}{l}I \pm 7.5 \\
\text { months }\end{array}$ & TTE & $\begin{array}{l}\mathrm{ZVa}(>4.7) \text { predicted } \\
\text { onset of symptoms } \\
\text { (dyspnea, angina, } \\
\text { syncope), AVR, death }\end{array}$ \\
\hline $\begin{array}{l}\text { Lancellotti, }{ }^{36} \\
2010\end{array}$ & 163 & $\begin{array}{l}\text { Moderate to } \\
\text { severe }\end{array}$ & $66+9$ & $\begin{array}{l}20 \pm 19 \\
\text { months }\end{array}$ & TTE & $\begin{array}{l}\mathrm{ZVa}(\geq 4.9) \text { predicted } \\
\text { onset of symptoms, } \\
\mathrm{AVR} \text {, death }\end{array}$ \\
\hline $\begin{array}{l}\text { Hachicha, }{ }^{37} \\
2009\end{array}$ & 544 & $\begin{array}{l}\text { At least } \\
\text { moderate, } \\
\text { defined as peak } \\
\text { velocity }>2.5 \mathrm{~m} / \mathrm{s}\end{array}$ & $66 \pm 7$ & $\begin{array}{l}2.5 \pm 1.8 \\
\text { years }\end{array}$ & TTE & $\begin{array}{l}\text { Higher } \mathrm{ZVa}(\geq 3.5) \\
\text { was associated with } \\
\text { increased mortality } \\
\text { when compared with } \\
\mathrm{ZVa}<3.5\end{array}$ \\
\hline Rieck, $^{33} 2012$ & 1,418 & Mild to moderate & $66 \pm 7$ & $\begin{array}{l}43 \pm 14 \\
\text { months }\end{array}$ & TTE & $\begin{array}{l}\text { High } \mathrm{ZVa}(>5) \\
\text { predicted increased } \\
\text { major cardiovascular } \\
\text { events and aortic valve } \\
\text { events, but did not } \\
\text { predict survival }\end{array}$ \\
\hline
\end{tabular}


Table 4 (Continued)

\begin{tabular}{|c|c|c|c|c|c|c|}
\hline $\begin{array}{l}\text { First author, } \\
\text { year }\end{array}$ & $\begin{array}{l}\text { Total } \\
\text { number of } \\
\text { patients } \\
\text { studied, } \mathbf{N}\end{array}$ & $\begin{array}{l}\text { Severity of } \\
\text { AS in study } \\
\text { population at } \\
\text { baseline }\end{array}$ & $\begin{array}{l}\text { Baseline } \\
\text { LVEF, \% } \\
\text { (mean } \pm \\
\text { SD) }\end{array}$ & $\begin{array}{l}\text { Mean } \\
\text { follow-up }\end{array}$ & Technique & \begin{tabular}{|l|} 
Main findings \\
(ZVa values are \\
described in \\
$\mathrm{mmHg} / \mathrm{ml} / \mathrm{m}^{2}$ )
\end{tabular} \\
\hline Magne, ${ }^{38} 2015$ & 676 & $\begin{array}{l}\text { Severe, defined } \\
\text { as } A V \text { area } \leq 1 \\
\mathrm{~cm}^{2} \text {, derived } \\
\text { from cardiac } \\
\text { catheterization } \\
\text { using Gorlin } \\
\text { equation }\end{array}$ & $72 \pm 10$ & $\begin{array}{l}4.5 \pm 2.9 \\
\text { years }\end{array}$ & $\begin{array}{l}\text { Cardiac } \\
\text { catheterization }\end{array}$ & $\begin{array}{l}\text { High ZVa }(>5) \text { was } \\
\text { significantly associated } \\
\text { with increased } \\
\text { mortality }\end{array}$ \\
\hline \multicolumn{7}{|c|}{ ZVa and Symptoms } \\
\hline $\begin{array}{l}\text { Harada, }{ }^{42} \\
2013\end{array}$ & 451 & $\begin{array}{l}\text { Moderate to } \\
\text { severe }\end{array}$ & $62.6 \pm 10.3$ & - & TTE & $\begin{array}{l}\text { Higher ZVa }(\geq 4.7) \\
\text { was associated with } \\
\text { increased risk of } \\
\text { syncope }\end{array}$ \\
\hline $\begin{array}{l}\text { Kruszelnicka } \\
\text { et al, } 2015^{40}\end{array}$ & 157 & $\begin{array}{l}\text { Moderate to } \\
\text { severe }\end{array}$ & $52.3 \pm 12$ & - & TTE & $\begin{array}{l}\text { Mean ZVa by HF class: } \\
\text { No symptoms: } 5 . I \\
\text { NYHA II: } 5.2 \\
\text { NYHA III-IV: } 5.7 \\
\text { Each decrease in SAC } \\
\text { by } 0.1 \mathrm{~mL} / \mathrm{m}^{2} \text { per } \\
\mathrm{mmHg} \text { was associated } \\
\text { with an increased } \\
\text { adjusted odds ratio } \\
\text { of a patient being in } \\
\text { one higher category of } \\
\text { NYHA class }\end{array}$ \\
\hline \multicolumn{7}{|c|}{ ZVa and mortality } \\
\hline $\begin{array}{l}\text { Lindman, }^{43} \\
2017\end{array}$ & $2,|4|$ & Severe & $54 \pm 11$ & $\begin{array}{l}30 \text { days to } \\
\text { I year }\end{array}$ & TTE & $\begin{array}{l}\text { Increased risk of } \\
\text { mortality with every } \\
\text { I unit increase in } \mathrm{ZVa} \\
\text { (baseline mean } \mathrm{ZVa} \\
\text { 3.99) }\end{array}$ \\
\hline $\begin{array}{l}\text { Giannini, }^{18} \\
2012\end{array}$ & 102 & Severe & $48.9 \pm 10.3$ & $\begin{array}{l}6 \text { months } \\
\text { post } \\
\text { TAVR }\end{array}$ & TTE & $\begin{array}{l}\text { Increased mortality } \\
\text { with higher baseline } \\
\mathrm{ZVa}(8.13 \text { vs } 6.4 \mathrm{I})\end{array}$ \\
\hline $\begin{array}{l}\text { Kobayashi, }{ }^{23} \\
2017\end{array}$ & 128 & Severe & $54 \pm 13$ & 376 days & TTE & $\begin{array}{l}\text { High baseline } \mathrm{ZVa}(>5) \\
\text { was associated with } \\
\text { higher mortality }\end{array}$ \\
\hline $\begin{array}{l}\text { Katsanos, }^{22} \\
2013\end{array}$ & 116 & Severe & $54 \pm 14$ & 25 months & TTE & $\begin{array}{l}\text { Baseline } \mathrm{ZVa}(\geq 5) \\
\text { associated with } \\
\text { increased all-cause } \\
\text { mortality }\end{array}$ \\
\hline $\begin{array}{l}\text { Katayama, }{ }^{44} \\
2015\end{array}$ & 177 & Severe & $65 \pm 6.5$ & $\begin{array}{l}5 \text { years } \\
\text { post SAVR }\end{array}$ & TTE & $\begin{array}{l}\text { Baseline high } Z V a \\
(\geq 4.3) \text { was not } \\
\text { associated with overall } \\
\text { mortality. }\end{array}$ \\
\hline \multicolumn{7}{|c|}{ ZVa in low flow, low gradient AS } \\
\hline Ngiam, ${ }^{47} 2017$ & 203 & Severe & $64 \pm 12.5$ & $3 \pm 2$ years & TTE & $\begin{array}{l}\text { High initial } Z \mathrm{ZVa}(>4.7) \\
\text { was associated with } \\
\text { switch from normal } \\
\text { flow to low flow } \\
\text { category }\end{array}$ \\
\hline
\end{tabular}

(Continued) 
Table 4 (Continued)

\begin{tabular}{|c|c|c|c|c|c|c|}
\hline $\begin{array}{l}\text { First author, } \\
\text { year }\end{array}$ & $\begin{array}{l}\text { Total } \\
\text { number of } \\
\text { patients } \\
\text { studied, } \mathbf{N}\end{array}$ & $\begin{array}{l}\text { Severity of } \\
\text { AS in study } \\
\text { population at } \\
\text { baseline }\end{array}$ & $\begin{array}{l}\text { Baseline } \\
\text { LVEF, \% } \\
\text { (mean } \pm \\
\text { SD) }\end{array}$ & $\begin{array}{l}\text { Mean } \\
\text { follow-up }\end{array}$ & Technique & $\begin{array}{l}\text { Main findings } \\
\text { (ZVa values are } \\
\text { described in } \\
\mathrm{mmHg} / \mathrm{ml}^{\prime} \mathrm{m}^{2} \text { ) }\end{array}$ \\
\hline $\begin{array}{l}\text { Herrmann, }{ }^{48} \\
2015\end{array}$ & 77 & $\begin{array}{l}\text { Any AS (non- } \\
\text { severe and } \\
\text { severe) }\end{array}$ & Any LVEF & $\begin{array}{l}3.3 \pm 1.7 \\
\text { years }\end{array}$ & $\begin{array}{l}\text { TTE with 2D } \\
\text { speckle tracking }\end{array}$ & $\begin{array}{l}\mathrm{ZVa} \text { was elevated at } \\
\text { baseline in the LF-LG } \\
\text { group compared } \\
\text { with NF/LG and } \\
\mathrm{HG} / \mathrm{AS} \text { groups (LF/ } \\
\mathrm{LG}, 3.2 \pm 0.8 ; \mathrm{NF} / \\
\mathrm{LG}, 2.2 \pm 0.5 ; \mathrm{HG} / \mathrm{AS} \text {, } \\
2.2 \pm 0.9 \text { ) }\end{array}$ \\
\hline $\begin{array}{l}\text { Mizia-Stec, }{ }^{49} \\
2011\end{array}$ & 44 & Severe AS & $>50$ & - & TTE & $\begin{array}{l}\mathrm{ZVa} \text { was higher in } \\
\text { patients with SVI } \\
<35 \mathrm{~mL} / \mathrm{m}^{2}(7.60) \\
\text { compared with those } \\
\text { with } \mathrm{SVI} \geq 35 \mathrm{~mL} / \mathrm{m}^{2} \\
(4.06)\end{array}$ \\
\hline Levy, ${ }^{51} 201 \mathrm{I}$ & 184 & $\begin{array}{l}\text { Severe low flow } \\
\text { low gradient }\end{array}$ & $29 \pm 7$ & 5 years & TTE, DSE & $\begin{array}{l}\text { ZVa was higher } \\
\text { in patients with } \\
\text { contractile reserve vs } \\
\text { without on DSE ( } 5.8 \\
\text { vs } 5.3 \text { ), however, failec } \\
\text { to distinguish pseudo } \\
\text { vs true severe AS nor } \\
\text { predict mortality after } \\
\text { AVR }\end{array}$ \\
\hline $\begin{array}{l}\text { Lancellotti, } \\
2010\end{array}$ & 173 & Severe AS & $66.5 \pm 7.3$ & - & $\begin{array}{l}\text { TTE with 2D } \\
\text { speckle tracking }\end{array}$ & $\begin{array}{l}\text { Higher prevalence } \\
\text { of elevated } Z V_{a}(\geq 5) \\
\text { in low flow group } \\
\text { compared with norma } \\
\text { flow }\end{array}$ \\
\hline $\begin{array}{l}\text { Hachicha, }{ }^{50} \\
2007\end{array}$ & 512 & Severe & $65 \pm 7.5$ & $\begin{array}{l}25 \pm 19 \\
\text { months }\end{array}$ & TTE & $\begin{array}{l}\text { Higher ZVa }(>5.5) \\
\text { was associated with } \\
\text { increased mortality }\end{array}$ \\
\hline
\end{tabular}

Abbreviations: AS, aortic stenosis; AV, aortic valve; DSE, dobutamine stress echocardiography; HG/AS, high gradient, aortic stenosis; LF-LG, low flow, low gradient; LV, left ventricle; LVEF, left ventricular ejection fraction; NF/LG, normal flow, low gradient; SAVR, surgical aortic valve replacement; TAVR, transcatheter aortic valve replacement; TTE, transthoracic echocardiography; ZVa, valvuloarterial impedance.

limitations and was of a very restricted cohort with limited generalizability. ${ }^{44}$

\section{Low flow-low gradient AS (LF-LG AS)}

A higher proportion of patients with LF-LG AS have hypertension and are at advanced age compared with those with other types of AS. For energetically efficient systolic ejection, ventricular elastance should be matched to aortic elastance. ${ }^{45}$ In the context of paradoxical AS, that is, LF-LG AS with preserved LVEF, LV compliance is low and arterial stiffness is high, resulting in a high grade ventriculoarterial coupling mismatch. This means that a greater proportion of the ventricular work is wasted rather than being used to generate the high gradient that it otherwise would have in regular AS as described by Braunwald. This represents the main pathology in paradoxical AS, in contrast to LF-LG AS with reduced LVEF, where impaired myocardial contractility cannot generate adequate flow. For the same reason, dobutamine stress echocardiogram is much less helpful in LF-LG AS with preserved LVEF.

In animal models and further validated in humans, low SAC reduced MPG for any degree of AS severity, even with stable transvalvular flow and in the absence of hypertension. ${ }^{46}$ In an interesting retrospective analysis, severe AS patients with higher baseline ZVa and initially normal flow ended up in the low flow category at 3 years, despite no change in MPG. In the same study, low flow AS patients with a follow-up decrease in ZVa were more likely to end up in the normal flow category. A similar association was observed with SAC. ${ }^{47}$ In another study with 3 years of follow-up over disease progression 
from non-severe to severe AS, SVR and ZVa were elevated not only at baseline, but they also identified a significantly higher absolute increase in low flow AS patients irrespective of LVEF compared with high gradient AS patients. Similarly, SAC was low at baseline and decreased most in the low flow AS group. ${ }^{48}$ High ZVa and low SAC were more prevalent in asymptomatic low flow patients with preserved LVEF $(\mathrm{n}=173)^{30}$ and again in a large SEAS sub-study. ${ }^{31}$ Consistent with these results, in a small cross-sectional study of patients with low flow severe AS with preserved LVEF, SAC was lower and SVR and ZVa were higher in patients with SVIs $<35 \mathrm{~mL} /$ $\mathrm{m}^{2} .{ }^{49}$ Finally, 3-year survival was worse in the high ZVa group in patients with paradoxical AS. ${ }^{50}$

In the only study involving exclusively low LVEF (mean LVEF 29\%) patients with LF-LGAS analyzed retrospectively from a multicenter registry, ${ }^{51} \mathrm{ZVa}$ was not predictive of either overall or perioperative mortality at 5 years. ZVa was higher in patients with contractile reserve compared with patients without contractile reserve, but it could not differentiate true vs pseudo-severe AS on dobutamine stress echocardiogram, perhaps because the SBP had decreased more in patients with higher ZVa. This also reminds us that, like other parameters for $\mathrm{AS}, \mathrm{ZVa}$ is also flow dependent and is even more susceptible to variability in the low flow state. Interestingly, patients with very low LVEF ( $\leq 20 \%$ ) had particularly high global afterload as measured by ZVa. Whether high combined valvular and vascular load is the cause of myocardial dysfunction and low LVEF or the ventriculoarterial uncoupling is in fact the consequence of low LVEF from myocardial dysfunction remains to be ascertained and needs further sophisticated studies.

\section{Conclusion}

Degenerative AS should be considered a systemic disease involving the ventricle, the valve, and the vessel, and each needs to be addressed individually to manage the disease in totality. The importance of non-valvular parameters has been proven, as low SAC and high ZVa predict dyspnea and syncope, respectively, irrespective of AS severity and predict LV remodeling and deformation in all planes.

Hypertension and TAVR are closely related, and TAVR has a palpable effect on downstream vascular properties, both immediate and in the long term. Pre-TAVR, low SAC reduces the calculated severity (gradient) of AS. Post TAVR, hypertension develops in almost half of patients, and postTAVR patients without a rise in BP and low SAC have poor outcomes. Additionally, TAVR changes the left ventricular outflow tract geometry, flow pattern, and resistive properties; therefore, gradient alone is not a reliable marker of success.
ZVa has shown to be predictive of adverse outcomes in a wide spectrum of patients with degenerative AS from moderate-to-severe asymptomatic stage $\mathrm{C}$, classical high gradient with preserved LVEF, stage D1, paradoxical stage D3, and even after TAVR; the only exception is in low flow, low gradient with reduced LVEF patients. The LF-LG with reduced LVEF state may represent a late stage of disease where the deleterious effects of other factors, such as coronary artery disease or advanced myocardial dysfunction overshadow the deleterious consequences of ZVa.

As the cohort of patients undergoing SAVR is different from TAVR (inoperable to high-risk surgical candidates due to multiple comorbidities), the current literature for postintervention changes in $\mathrm{ZVa}$ and $\mathrm{SAC}$ cannot be compared. Aortic stunning, the level of anesthesia, bypass circuits, and cardioplegia are other procedural differences between TAVR and SAVR that may account for differences in ZVa.

\section{Perspective: hypertension goes parallel when it comes to prognosis}

High ZVa and low SAC predict and/or confer an adverse risk (LV remodeling, worse strain pattern, clinical symptoms, and all-cause mortality) independent of AS severity. This suggests that ZVa and SAC and not just MPG should be used as markers of therapeutic success after TAVR. Interestingly, in most studies, patients with high ZVa were more frequently female. This could be due to the known fact that post-menopausal females have intrinsically stiffer large vessels than age-matched males. ${ }^{52}$

The management of asymptomatic patients with severe AS is controversial. As opposed to the conventional view of severe AS being of fixed resistance, it is rather a dynamic process with a poor correlation between area, gradient, and flow, especially during stress; that is, exertional symptoms. ${ }^{53-55}$ We suggest including $\mathrm{ZVa}$ in addition to conventional parameters in these patients to decide on AV replacement even in the absence of symptoms, especially since the risk of and complications from TAVR are always reducing. It is time to move on from flow-dependent stenosis geometry (AVA) and incorporate global load to predict the need for AV replacement.

Isolated systolic hypertension and increased PP are derivatives of reduced SAC, and the presence of these findings signifies that both vessel and valve are compromised. Moreover, in the late stages or perhaps in different phenotypes altogether, once SVi is reduced, it may falsely cure the hypertension as measured by SBP and PP alone in LF-LGAS patients. In these cases, the importance of SAC and $\mathrm{ZVa}$ is 
even greater, as measuring them will unmask high global LV load beneath seemingly normal hemodynamics. An absence of a high ZVa in LF-LG patients may also suggest that the low gradient is due to intrinsic ventricular dysfunction rather than ventriculoarterial uncoupling.

Though the SPRINT trial led to guideline changes of a target SBP of $<130 \mathrm{mmHg}$, studies involving typical TAVR patients showed greater mortality with SBPs $<129 \mathrm{mmHg}$. Old age, high prevalence of diabetes (which also worsens arterial stiffness), and ventriculoarterial uncoupling are some obvious differences why the new BP guidelines are not applicable to current-era post-TAVR patients.

\section{Author contributions}

Both authors contributed to data analysis, drafting and revising the article, gave final approval of the version to be published, and agree to be accountable for all aspects of the work.

\section{Disclosure}

The authors report no conflicts of interest in this work.

\section{References}

1. Braunwald RJE. Aortic stenosis. Circulation. 1968;38(1 Suppl):61-67.

2. Osnabrugge RL, Mylotte D, Head SJ, et al. Aortic stenosis in the elderly: disease prevalence and number of candidates for transcatheter aortic valve replacement: a meta-analysis and modeling study. J Am Coll Cardiol. 2013;62(11):1002-1012.

3. Antonini-Canterin F, Huang G, Cervesato E, et al. Symptomatic aortic stenosis: does systemic hypertension play an additional role? Hypertension. 2003;41(6):1268-1272.

4. Rieck AE, Cramariuc D, Staal EM, Rossebø AB, Wachtell K, Gerdts E. Impact of hypertension on left ventricular structure in patients with asymptomatic aortic valve stenosis (a SEAS substudy. J Hypertens. 2010;28(2):377-383.

5. Stewart BF, Siscovick D, Lind BK, et al. Clinical factors associated with calcific aortic valve disease. Cardiovascular Health Study. J Am Coll Cardiol. 1997;29(3):630-634.

6. Rieck ÅE, Cramariuc D, Boman K, et al. Hypertension in aortic stenosis: implications for left ventricular structure and cardiovascular events. Hypertension. 2012;60(1):90-97.

7. Mitchell GF. Pulse pressure, arterial compliance and cardiovascular morbidity and mortality. Curr Opin Nephrol Hypertens. 1999;8(3):335-342.

8. de Simone G, Roman MJ, Koren MJ, Mensah GA, Ganau A, Devereux RB. Stroke volume/pulse pressure ratio and cardiovascular risk in arterial hypertension. Hypertension. 1999;33(3):800-805.

9. Zieman SJ, Melenovsky V, Kass DA, Mechanisms KDA. Mechanisms, pathophysiology, and therapy of arterial stiffness. Arterioscler Thromb Vasc Biol. 2005;25(5):932-943.

10. Schram MT, Kostense PJ, van Dijk RA, et al. Diabetes, pulse pressure and cardiovascular mortality: the Hoorn study. J Hypertens. 2002;20(9):1743-1751.

11. Mozos I, Malainer C, Horbańczuk J, et al. Inflammatory markers for arterial stiffness in cardiovascular diseases. Front Immunol. 2017;8:1058.

12. Briand M, Dumesnil JG, Kadem L, et al. Reduced systemic arterial compliance impacts significantly on left ventricular afterload and function in aortic stenosis: implications for diagnosis and treatment. $J \mathrm{Am}$ Coll Cardiol. 2005;46(2):291-298.
13. Maréchaux S, Carpentier E, Six-Carpentier M, et al. Impact of valvuloarterial impedance on left ventricular longitudinal deformation in patients with aortic valve stenosis and preserved ejection fraction. Arch Cardiovasc Dis. 2010;103(4):227-235.

14. Shim Y, Hampton TG, Straley CA, et al. Ejection load changes in aortic stenosis. Observations made after balloon aortic valvuloplasty. Circ Res. 1992;71(5):1174-1184.

15. Yotti R, Bermejo J, Gutiérrez-Ibañes E, et al. Systemic vascular load in calcific degenerative aortic valve stenosis: insight from percutaneous valve replacement. J Am Coll Cardiol. 2015;65(5):423-433.

16. Perlman GY, Loncar S, Pollak A, et al. Post-procedural hypertension following transcatheter aortic valve implantation: incidence and clinical significance. JACC Cardiovasc Interv. 2013;6(5):472-478.

17. Pasipoularides A. Clinical assessment of ventricular ejection dynamics with and without outflow obstruction. J Am Coll Cardiol. 1990;15(4):859-882.

18. Giannini C, Petronio AS, de Carlo M, et al. The incremental value of valvuloarterial impedance in evaluating the results of transcatheter aortic valve implantation in symptomatic aortic stenosis. $J$ Am Soc Echocardiogr. 2012;25(4):444-453.

19. di Bello V, Giannini C, de Carlo M, et al. Acute improvement in arterialventricular coupling after transcatheter aortic valve implantation (CoreValve) in patients with symptomatic aortic stenosis. Int J Cardiovasc Imaging. 2012;28(1):79-87.

20. Chrissoheris M, Ziakas A, Chalapas A, et al. Acute invasive hemodynamic effects of transcatheter aortic valve replacement. J Heart Valve Dis. 2016;25(2):162-172.

21. Vavuranakis M, Vrachatis DA, Boudoulas H, et al. Effect of transcatheter aortic valve implantation on the ascending aorta's elasticity. Clin Res Cardiol. 2012;101(11):895-899.

22. Katsanos S, Yiu KH, Clavel MA, et al. Impact of valvuloarterial impedance on 2-year outcome of patients undergoing transcatheter aortic valve implantation. J Am Soc Echocardiogr. 2013;26(7):691-698.

23. Kobayashi Y, Kim JB, Moneghetti KJ, et al. Dynamic changes in aortic impedance after transcatheter aortic valve replacement and its impact on exploratory outcome. Int J Cardiovasc Imaging. 2017;33(11):1693-1701.

24. Styczynski G, Rdzanek A, Pietrasik A, et al. Echocardiographic assessment of aortic pulse-wave velocity: validation against invasive pressure measurements. J Am Soc Echocardiogr. 2016;29(11):1109-1116.

25. Pagel PS, Schroeder AR, de Vry DJ, Hudetz JA. Aortic valve replacement reduces valvuloarterial impedance but does not affect systemic arterial compliance in elderly men with degenerative calcific trileaflet aortic valve stenosis. J Cardiothorac Vasc Anesth. 2014;28(6):1540-1544.

26. Ito H, Mizumoto T, Shomura Y, Sawada Y, Kajiyama K, Shimpo H. The impact of global left ventricular afterload on left ventricular reverse remodeling after aortic valve replacement. J Card Surg. 2017;32(9):530-536.

27. Costantino MF, Galderisi M, Dores E, et al. Parallel improvement of left ventricular geometry and filling pressure after transcatheter aortic valve implantation in high risk aortic stenosis: comparison with major prosthetic surgery by standard echo Doppler evaluation. Cardiovasc Ultrasound. 2013;11:18.

28. Musa TA, Uddin A, Fairbairn TA, et al. Assessment of aortic stiffness by cardiovascular magnetic resonance following the treatment of severe aortic stenosis by TAVI and surgical AVR. J Cardiovasc Magn Reson. 2016;18(1):37.

29. Jang JY, Seo JS, Sun BJ, et al. Impact of valvuloarterial impedance on concentric remodeling in aortic stenosis and its regression after valve replacement. J Cardiovasc Ultrasound. 2016;24(3):201-207.

30. Lancellotti P, Donal E, Magne J, et al. Impact of global left ventricular afterload on left ventricular function in asymptomatic severe aortic stenosis: a two-dimensional speckle-tracking study. Eur J Echocardiogr. 2010;11(6):537-543.

31. Cramariuc D, Cioffi G, Rieck AE, et al. Low-flow aortic stenosis in asymptomatic patients: valvular-arterial impedance and systolic function from the SEAS substudy. JACC Cardiovasc Imaging. 2009;2(4):390-399. 
32. Holmes AA, Taub CC, Garcia MJ, Shan J, Slovut DP. Increased apical rotation in severe aortic stenosis is associated with reduced survival: a speckle-tracking study. JAm Soc Echocardiogr. 2015;28(11):1294-1301.

33. Rieck AE, Gerdts E, Lønnebakken MT, et al. Global left ventricular load in asymptomatic aortic stenosis: covariates and prognostic implication (the SEAS trial). Cardiovasc Ultrasound. 2012;10:43.

34. Ramamurthi A, Pandian NG, Gangadharamurthy D, et al. The syndrome of degenerative calcific aortic stenosis: prevalence of multiple pathophysiologic disorders in association with valvular stenosis and their implications. Echocardiography. 2013;30(1):1-7.

35. Zito C, Salvia J, Cusmà-Piccione $M$, et al. Prognostic significance of valvuloarterial impedance and left ventricular longitudinal function in asymptomatic severe aortic stenosis involving three-cuspid valves. $\mathrm{Am}$ J Cardiol. 2011;108(10):1463-1469.

36. Lancellotti P, Donal E, Magne J, et al. Risk stratification in asymptomatic moderate to severe aortic stenosis: the importance of the valvular, arterial and ventricular interplay. Heart. 2010;96(17):1364-1371.

37. Hachicha Z, Dumesnil JG, Pibarot P. Usefulness of the valvuloarterial impedance to predict adverse outcome in asymptomatic aortic stenosis. J Am Coll Cardiol. 2009;54(11):1003-1011.

38. Magne J, Mohty D, Boulogne C, et al. Prognostic impact of global left ventricular hemodynamic afterload in severe aortic stenosis with preserved ejection fraction. Int J Cardiol. 2015;180:158-164.

39. Huded CP, Masri A, Kusunose K, et al. Outcomes in asymptomatic severe aortic stenosis with preserved ejection fraction undergoing rest and treadmill stress echocardiography. J Am Heart Assoc. 2018;7(8): e007880.

40. Kruszelnicka O, Chmiela M, Bobrowska B, et al. Depressed systemic arterial compliance is associated with the severity of heart failure symptoms in moderate-to-severe aortic stenosis: a cross-sectional retrospective study. Int J Med Sci. 2015;12(7):552-558.

41. Albu A, Fodor D, Bondor C, Poantă L. Arterial stiffness, carotid atherosclerosis and left ventricular diastolic dysfunction in postmenopausal women. Eur J Intern Med. 2013;24(3):250-254.

42. Harada K, Saitoh T, Tanaka J, Shibayama K, Berdejo J, Shiota T. Valvuloarterial impedance, but not aortic stenosis severity, predicts syncope in patients with aortic stenosis. Circ Cardiovasc Imaging. 2013;6(6):1024-1031.

43. Lindman BR, Otto CM, Douglas PS, et al. Blood pressure and arterial load after transcatheter aortic valve replacement for aortic stenosis. Circ Cardiovasc Imaging. 2017;10(7): pii: e006308.
44. Katayama M, Najib MQ, Marella PC, Temkit MH, Belohlavek M, Chaliki HP. Does valvuloarterial impedance impact prognosis after surgery for severe aortic stenosis in the elderly? Open Heart. 2015;2(1):e000241.

45. Walley KR. Left ventricular function: time-varying elastance and left ventricular aortic coupling. Crit Care. 2016;20:270.

46. Côté N, Simard L, Zenses AS, et al. Impact of vascular hemodynamics on aortic stenosis evaluation: new insights into the pathophysiology of normal flow-small aortic valve area-low gradient pattern. J Am Heart Assoc. 2017;6(7):e006276.

47. Ngiam JN, Kuntjoro I, Tan BYQ, et al. Predicting changes in flow category in patients with severe aortic stenosis and preserved left ventricular ejection fraction on medical therapy. Echocardiography. 2017;34(11):1568-1574.

48. Herrmann S, Fries B, Liu D, et al. Differences in natural history of low- and high-gradient aortic stenosis from nonsevere to severe stage of the disease. J Am Soc Echocardiogr. 2015;28(11):1270-1282.

49. Mizia-Stec K, Adamczyk T, Mizia M, et al. Low-flow severe aortic stenosis with preserved ejection fraction, N-terminal pro-brain natriuretic peptide (NT-proBNP) and cardiovascular remodeling. J Heart Valve Dis . 2011;20(3):301-310.

50. Hachicha Z, Dumesnil JG, Bogaty P, Pibarot P. Paradoxical low-flow, low-gradient severe aortic stenosis despite preserved ejection fraction is associated with higher afterload and reduced survival. Circulation. 2007;115(22):2856-2864.

51. Levy F, Luc Monin J, Rusinaru D, et al. Valvuloarterial impedance does not improve risk stratification in low-ejection fraction, low-gradient aortic stenosis: results from a multicentre study. Eur J Echocardiogr. 2011;12(5):358-363.

52. Rossi P, Francès Y, Kingwell BA, Ahimastos AA. Gender differences in artery wall biomechanical properties throughout life. J Hypertens. 2011;29(6):1023-1033.

53. Goublaire C, Melissopoulou M, Lobo D, et al. Prognostic Value of exercise-stress echocardiography in asymptomatic patients with aortic valve stenosis. JACC Cardiovasc Imaging. 2018;11(6):787-795.

54. Van Zalen JJ, Badiani S, Hart L, Marshall A, Patel N, Lloyd G. The importance of contractile reserve when assessing asymptomatic patients with aortic stenosis. Eur Heart J Cardiovasc Imaging. 2016;17(Suppl 2):ii95-ii102).

55. Johnson NP, Zelis JM, Tonino PAL, et al. Pressure gradient vs. flow relationships to characterize the physiology of a severely stenotic aortic valve before and after transcatheter valve implantation. Eur Heart J. 2018;39(28):2646-2655.
Integrated Blood Pressure Control

\section{Publish your work in this journal}

Integrated Blood Pressure Control is an international, peer-reviewed open-access journal focusing on the integrated approach to managing hypertension and risk reduction. Treating the patient and comorbidities together with diet and lifestyle modification and optimizing healthcare resources through a multidisciplinary team approach constitute key

\section{Dovepress}

features of the journal. This journal is indexed on American Chemical Society's Chemical Abstracts Service (CAS). The manuscript management system is completely online and includes a very quick and fair peerreview system, which is all easy to use. Visit http://www.dovepress.com/ testimonials.php to read real quotes from published authors. 